\title{
The Spatial Strategy of Urban Planning for an Industry-Based City in Taiwan under Japanese Colonial Rule - The Case of Pingtung City
}

\author{
Chuan-Hsiang Hung, Ming-Hsien Ko, and Sen-I Tsai
}

\begin{abstract}
The industrial revolution has changed our society and living environment. In the early twentieth century, following Emperor Meiji's policy of Westernization, the Japanese colonial government introduced primary industries to Taiwan along with the western infrastructure and spatial planning, and Pingtung was one of the cities that received such innovations. Pingtung City's rise owed much to the economic policy of the Office of the Governor-General of Taiwan, and the city's transformation from a remote village to a new industry-oriented city in thirty years' time was achieved through space planning, which involved two major phases. This paper introduces Pingtung City's historical background and the process of its rise to economic prominence before the Second World War. Discussions and analyses will be conducted on the spatial strategy and adjustment in the first-phase urban development plans and on the spatial expansion and integration in the second-phase urban redevelopment plans. The differences in space-allocation strategies and design methods between the two stages will also be addressed.
\end{abstract}

Index Terms-Pingtung city, urban planning, Japanese colonial rule, industry-based city.

\section{INTRODUCTION}

In Taiwan, which is among the most densely populated places in the world, most people live in urban areas. In the last century, Taiwan witnessed the gradual transition from agriculture to industry. Towns and villages also went in the direction of urbanization. These modern developments started from the urban planning in the Japanese colonial period. The achievements of the Japanese effort laid the foundation for later progress in the cities of the island and contributed to the formation of the major metropolises in modern Taiwan. Over the hundred years, the urban layouts inscribed on the Taiwan soil have become part of Taiwanese living and served as the important scenery for collective memory. Pingtung City is a classical example in this regard.

During the period of Japanese occupation, the Japanese introduced modern urban planning system in Europe and America to Taiwan, such as development plan (市區改正). The Office of the Governor-General of Taiwan (or Taiwan Sotokufu) saw the potential of the land on the Pingtung Plain and decided to advance the cane sugar industry here. Pingtung City was chosen as the center for local development which conduced to the unique features of the city. Of the

Manuscript received November 24, 2015; revised January 28, 2016.

C.-H. Hung, M.-H. Ko, and S.-I Tsai are with the Department of Architecture, National Cheng Kung University, Taiwan (e-mail: hungch@mail.ncku.edu.tw, as007@ksts.seed.net.tw). prefecture-administered cities under Japanese rule, it was the only one that was planned and developed for a particular industry. It is the primary interest of the present paper to explore the spatial strategy employed in planning the city and analyze the blueprints, proposals, plots, and related literature. In view of the relationship of the urban construction with the development of the Pingtung Plain, the surrounding factors also play a key role, evidenced in the Neighborhood Map of Taiwan (臺灣堡圖, the 1904 edition), the Topographic Map of Taiwan (臺灣地形圖), and the Flood Control Map of the Lower Tamsui River (下淡水溪治水計畫圖). The spatial planning of this historic city is the focus of the present paper, but the main argument is constrained by the loss of some literature and the unrecognizability of some material. In addition, as Pingtung was listed as a strategic fortress of Kaohsiung in the late period of Japanese colonization, many documents, maps and illustrations were kept secret by the military for their sensitive significance, leaving very few accessible data for the public. This also compromises the cogency of this study. Notwithstanding, the aim of this paper is not so much to discuss historical material as to explicate the spatial prototype of a classical industry-based city. The present paper will center on the practice of spatial strategy, and discussion will focus on the urban planning projects officially recognized by the Office of the Governor-General. Urban planning theory, proposed drafts and unrealized schemes are not the concern of this study.

\section{ThE RISE OF THE SUGAR INDUSTRY City IN SOUTHERN} TAIWAN

A-Kau (阿猴), an old name of the Pingtung City, started as an unknown, obscure settlement and developed rapidly into Taiwan's eighth prefecture-administered city in a matter of thirty years. The rise of A-Kau was due in part to its advantageous location on the Pingtung Plain, and in part to the favorable policies of the Japanese colonial government. In order to achieve the aim of boosting industries, especially the cane sugar industry, the Office of the Governor-General of Taiwan continuously invested a lot of administrative resources in building the infrastructure and drafted urban development plans on a step-by-step basis. This was done to meet the spatial requirements of agricultural and administrative expansions as well as to integrate the agrarian resources on the Pingtung Plain.

\section{A. The Historical Context of the Pingtung Plain Development}

Originating in the East Peak of Jade Mountain, the Lower Tamsui River (renamed the Gaoping River in 1960) was the 
second longest river in Taiwan. With its watershed extending over the Central Mountain Range, Jade Mountain, and Ali Mountain, the river had the largest catchment area in Taiwan. Because the average annual precipitation was over $3000 \mathrm{~mm}$, mostly caused by torrential downpours from the rainy and typhoon seasons, there often occurred collapse of mountain walls, loss of surface soil, and a large-scale discharge of earth and sand in the stream, resulting in the high amount of sand in the Lower Tamsui River. It was owing to the earth, sand, and sediment carried by the river that the broad and fertile Pingtung Plain was formed.

In the early history of Taiwan, the development of the Pingtung Plain was relatively slow. This was mainly caused by the blockage of the Lower Tamsui River, the fragmentation of the land by the multiple tributaries, and the frequency of floods brought by heavy rain. However, the Pingtung Plain and the Kaohsiung Plain were only a few kilometers apart, separated from each other by the Lower Tamsui River (see Fig. 1). In the fiftieth year of Emperor Qianlong's reign, the Qing government relocated the Office of the Prefectural Assistant Officer from Aligang to A-Kau, and the new site was right next to the Tianhou Temple until Taiwan's cession to Japan. In terms of its geographical position, A-Kau was situated in the central area of the Pingtung Plain, and was adjacent to Fengshan's New Town. This geographical advantage was not utilized for development in the Qing Dynasty, but the superiority of its location was undeniable and conducive to its subsequent rise to prosperity in the Japanese occupation period.

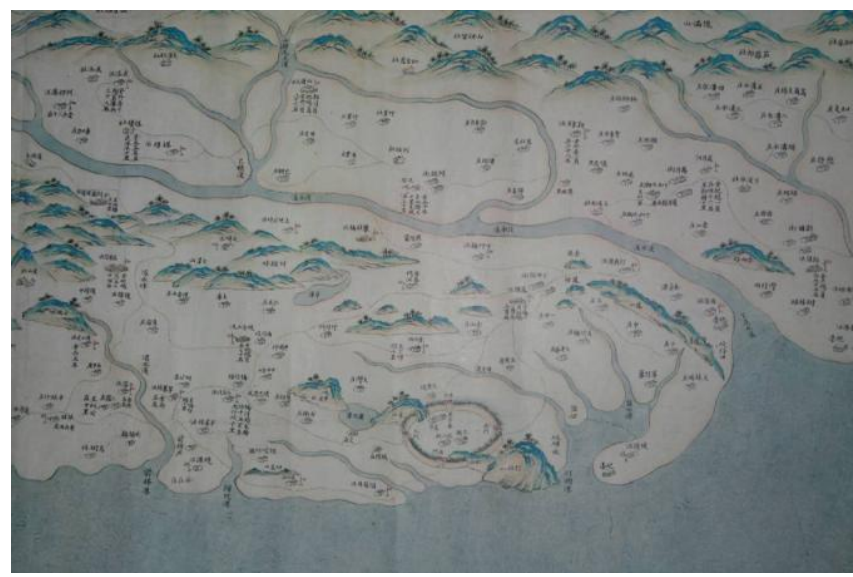

Fig. 1. The layout of the lower Tamsui river plain and Fengshan's old town during the Qianlong period [1].

The image is excerpted from the Complete Map of Taiwan issued during Qianlong's reign (1756-1759). A-Kau Street is represented on the map by the two houses on the upper left side of the point where the two rivers meet.

Despite its belated development, the Pingtung Plain soon thrived with crops of rice and sugarcane, owing to its expansiveness, its all-year-round high temperature with sufficient sunshine, and the profusion of rainfall. As early as in the late Qing period, the Plain was known for its production of cane sugar. However, the productive efficiency was inadequate and hard to improve, for the farmers were sparsely scattered, the production was small-scale and lagged behind in technology, and transportation was inconvenient. Upon taking over Taiwan, the Japanese government dispatched officials to survey Pingtung and gain an in-depth knowledge of the structure of local population and industries. Their observation of the private cane sugar factories was especially meticulous [2], betraying the colonial government's preconceived intention to develop the Plain.

\section{B. The Strategy of the Office of the Governor-General of Taiwan in Promoting the Cane Sugar Industry}

The Japanese preference for Taiwan's cane sugar did not come for no reason. In the late 19th century, Taiwan's cane sugar was a main export product, and Japan was its most important country of export destination [3]. In fact, exportation of Taiwan's cane sugar to Japan had started since the Dutch occupation period [4]. The sugar industry in Taiwan continued to grow in the Qing Dynasty, during which the Sugar Guild was among the most important Three Guilds in Tainan [5], [6]. After the Treaty of Tientsin (or Treaties of Tianjin, 1858) was signed, the imperial powers from the West gained access to the ports of Anping and Takao (now Kaohsiung), and Japan's market was again channeled [3]. In 1868, Emperor Meiji began his policy of westernizing Japan, and the demand for sugar rose drastically. In ten years' time, the importation of sugar had more than tripled in Japan [3]. In 1894 , the Japanese population consumed a total of 4,000,000 quintal sugar, but domestic production could only supply 800,000 quintal, so that $80 \%$ of the sugar had to depend on imports [7]. Consequently, after taking over Taiwan in 1895, the Office of the Governor-General actively endeavored to exploit the cane sugar industry in Taiwan so as to supply Japan's domestic need. In the following year, the Japanese started to improve the breed of sugarcane in order to maximize quality and production [7]. In 1898, the new Governor-General Kodama Gentaro（兒玉源太郎， 1852-1906) and the new Civil Affairs Department Governor Goto Shinpei (後藤新平, 1857-1929) came to Taiwan to take office, and soon the cane sugar production became Taiwan's strategic industry [7].

Under the Japanese policy, the Pingtung Plain, with its broadness and sugarcane-friendly climate, naturally became one of the important sites for development. In 1903, the Office of the Governor-General approved the establishment around A-Kau of Nanchang Sugar Corporation, run by the local gentry. However, four years later the company was acquired by Taiwan Sugar Corporation, a modern Japanese business [8], [9]. In 1909, the well-capitalized Taiwan Sugar set up a new factory in Guilai Village to the south of A-Kau. It was known as "New Peak of Taiwan Sugar," being the largest not only in Taiwan, but also in East Asia [10]. As the factory kept facilitating its production, railroad tracks were extended to the sugarcane fields on the Pingtung Plain for transportation of the raw material of sugar. The colonial government worked hand in hand with the Japanese firms on the Pingtung Plain to boost the cane sugar industry, which served as a key factor in triggering the development of Pingtung City.

\section{Upgrading the Administrative Status and Building the Infrastructure}

To comply with the government's policy, the Office of the Governor-General spared no effort in promoting the cane sugar industry. To achieve the desired results required the assistance and management of a local administrative agent, 
and the establishment of a prefecture directly under the central government was deemed the most effective. Hence, as Taiwan society was becoming increasingly stable, the Office of the Governor-General initiated a new administrative system in 1901, where the level of prefecture was adopted in place of the "county" level. A-Kau was upgraded to one of the twenty prefectures directly under the control of the Office of the Governor-General, and its Prefecture Office was located on A-Kau Street, giving its administration a brand-new horizon. With the reform of the local administrative system in 1909 , the twenty prefectures were merged and redivided into twelve prefectures. A-Kau Prefecture's administrative districts were broadened as a result, and its political and economic importance in the Lower Tamsui River and Hengchun areas was secured. In 1920, A-Kau Street was renamed Pingtung Street [11], [12]. Then, in the subsequent readjustments of Taiwan's local administrative system, Pingtung Street was elevated to Pingtung City of Takao Prefecture in 1933, making it the eighth prefecture-administered city (along with Changhua City). Thanks to the importance of sugar production, the Office of the Governor-General upgraded the administrative status of Pingtung to support the cane sugar industry.

In addition to administrative elevation, the security police unit and the army air squadron were also a contributory factor to Pingtung's prosperity. In 1919, the Police Administration Bureau decided to choose the Lower Tamsui River Plain to the west of A-Kau Street as the site for constabulary aviation training, a tactic where the airplane on patrol was expected to serve as a menace to the invading aboriginals from the mountain in southern Taiwan [8], [13]. Eight years later, the air training program for the police was terminated after completing its phased mission, and the base and facilities were committed to the charge of the Eighth Aviation Regiment of the Japanese Army [8], [13], the first aviation army stationed in Taiwan which also served as the jumping board for the Japanese armies to expand their military power over Southeast Asia and South China. The airfield brought here a large number of policemen from the aviation training program as well as a lot of servicemen from the army aviation regiment. The board and lodging and daily necessities for the new arrivals and the supply and maintenance of the military facilities also contributed to the spatial and business development of Pingtung Street.

Emulating the Western nations, the Japanese colonial government also began building the infrastructure in Taiwan, and a railway trunk line that stretched from the north to the south was a major project. The completion of the north-south railway in 1908 had a far-reaching impact in that for the first time it linked and integrated the towns and cities in western Taiwan. Its final stop in the south was situated at Jiuqutang, on the right bank of the Lower Tamsui River. In order to facilitate transportation of the staff, goods and building material through a smooth traffic linkage between A-Kau Prefecture Office, the sugar factories, the Takao Harbor, and the railway, the Office of the Governor-General sponsored the construction of the wooden bridge for sugar shipment across the Lower Tamsui River, and the bridge work was completed also in 1908 [8]. However, the wooden structure of the bridge could not be expected to last long. In fact, the Office of the Governor-General had long intended to extend the north-south railway trunk line to the Pingtung Plain, but the exceptional breadth and the treacherous water flow of the Lower Tamsui River made the cross-river connection technically hard to accomplish and thus deterred the construction of railway across the Pingtung area [10]. The railway bridge across the Lower Tamsui River was finally finished in 1913, followed by the official commencement of railway service between A-Kau Street and the Takao Habor a year later, marking the significant connection between the Pingtung Plain and the plains in western Taiwan, and making the 1908 wooden bridge exist for no reason. The Pingtung railway line and the local sugar-carrying spur lines conspired to turn A-Kau Street into the hub of transportation on the Pingtung Plain.

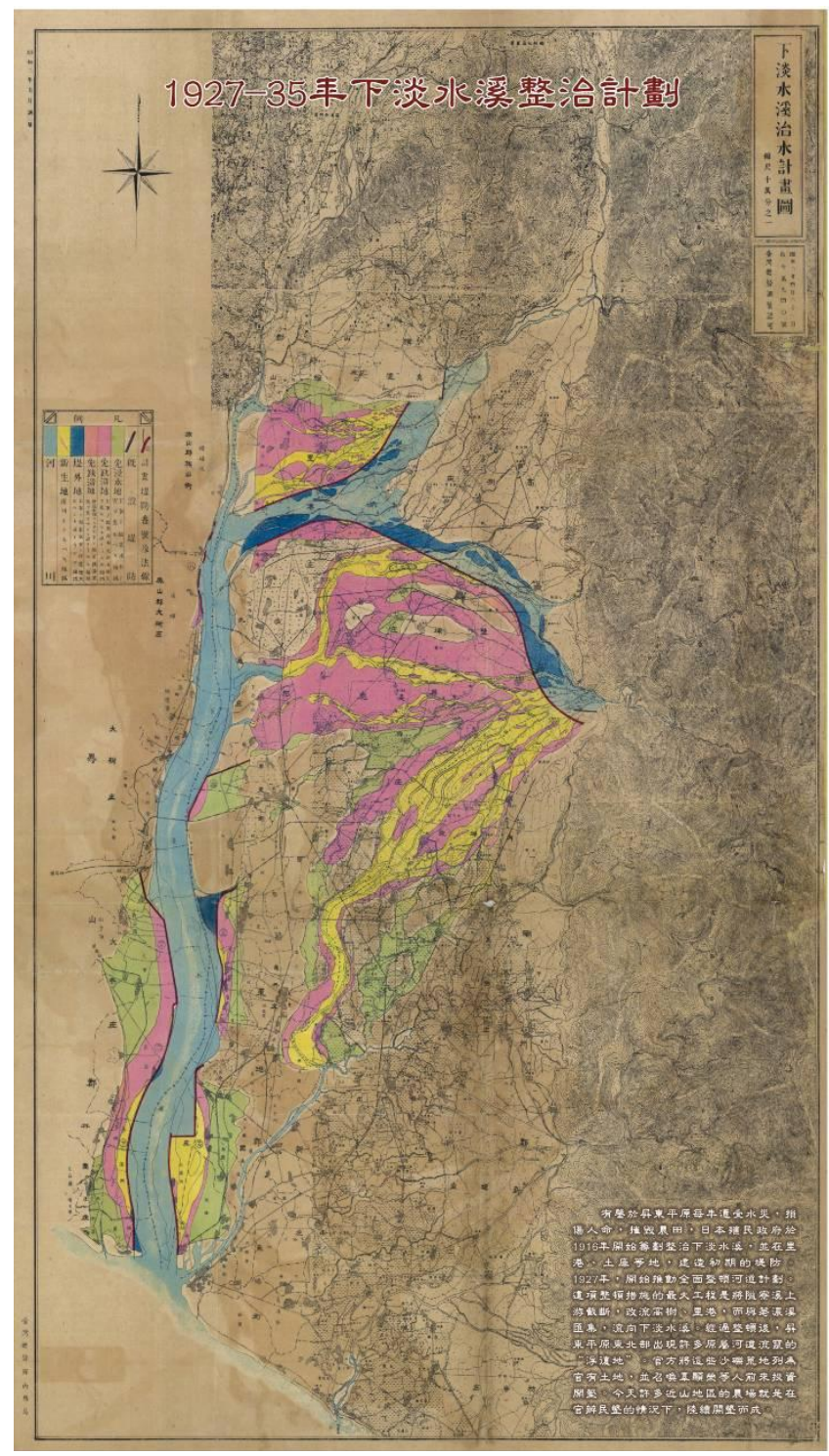

Fig. 2. The Lower Tamsui River Work Plan in 1927 [14].

On the other hand, though broad and spacious, the Pingtung Plain was troubled by the extensive overflow of streams (the Ailiao River and the Koushe River in particular), resulting in significant reduction of arable land, inconvenience of transportation, and frequent occurrence of floods. To tackle this problem, the Office of the Governor-General drafted a plan to regulate the course of the Lower Tamsui River in 1927 (see Fig. 2), which included construction of embankment at the Ailiao River and the 
Koushe River to direct the water flow into the Laonong River, on both sides of which levees were built to make the water run into the Lower Tamsui River. To prevent floods from damaging the farmland, authorities flanked the lower stretches of the Lower Tamsui River with dikes on both sides. In 1938, when the infrastructure of the river work was completed, the flood-prone Pingtung Plain gained momentum in development [15], [16]. Besides, with the shrinkage of water in the rivers emerged a lot of flood-free land, loss-free land, and reclaimed land, which enlarged the scale of agriculture, particularly the sugarcane plantation. Moreover, the disappearance of some crisscross streams also improved land transportation; the narrowed riverway made it easier to build a bridge across it; and inter-village roads were also constructed extensively. Armed with a railway line and located favorably, Pingtung City now came further to be the hub of highway communication and played a major role in regional development.

\section{Implementation and Expansion of the Urban Planning}

The development plans for Taichung and Taipei were announced and practiced in 1900, drawing up the curtain of Taiwan's modern urban planning. This was the Office of the Governor-General's blueprint for densely populated or promising areas to construct the infrastructure. During the period of Japanese occupation, authorities put forth successive development plans for A-Kau Street, Pingtung Street, and Pingtung City respectively. Announced in 1913, the development plan for A-Kau Street was the first stage of urban planning for Pingtung City. Following the timetable for the Pingtung railway construction, the project was a corollary of the expansion of A-Kau Prefecture's administrative district in 1909. The second stage of urban development was found in the Development Plan Map of Pingtung Street sanctioned by the Office of the Governor-General in 1930. However, it was just a fine-tuning of the old plan without any major change. As for the third stage of urban planning, the complete ideas were shown in the Plan Map of Pingtung City Development, approved by the Office of the Governor-General in 1934. It was drafted in response to the upgrade of Pingtung Street to Pingtung City, where the layout of the streets was altered in the expanded city area. This plan was the spatial prototype of Pingtung City after World War II.

This paper seeks to scrutinize and analyze the three maps mentioned in the previous paragraph. As a matter of fact, apart from the officially sanctioned plans, A-Kau Prefecture had also proposed local plans, but they were drastically modified by the Office of the Governor-General before adoption for use. In order to stay focused, the present paper does not discuss unrealized plans or the unapproved drafts that appeared after the Pingtung Street development plan. In addition, since the first two stages of urban planning fall on the local level without much difference between each other, they are addressed together in Section Three. The third stage of urban development, on the other hand, had a completely different contour and strategy in spatial arrangement, and so it will be explored in Section Four.

\section{The Spatial Structure AND AdJUSTMENT IN THE URBAN PLANNING}

Before the Japanese ruled Taiwan, the A-Kau settlement had taken shape. As the upheavals and turmoils that came with the transfer of government gradually died down, the Office of the Governor-General began to outline strategies of transforming existing towns and developing new cities, and urban development plans were among the top priorities. The 1913 plan for A-Kau Street development was first in the series of urban planning efforts, and it lay the foundation for the spatial development of the city. The 1930 plan for Pingtung Street development was a slightly modified version of its 1913 predecessor. In these two initial projects, the Pingtung section of the north-south railway line was the hub on which the urban planning revolved.

\section{A. The Prototypal Layout of the Earlier Settlements}

In the early 20th century, A-Kau Street was just a small settlement comprised of three converging streets (see Fig. 3). From the center of the settlement, one of the streets extended toward north-northeast, another went in the direction of west-southwest, and the other led toward south-southeast. The first two streets were a little longer than the third. Along the north-northeastward street, one could reach Aligang (now Ligang Township of Pingtung) via Jiukuai Village (now Jiuru Township of Pingtung), arrive at Yanpu Village via Haifeng Village, or get to Fanzailiao (now Fanziliao) via Huoshao Village (now Changxing Township). The west-southwest street took one directly to Cifeng Temple, from the north of which one could proceed to Liukuaicuo ferry crossing at the Lower Tamsui River, on the other side of which there was a path leading to Fengshan. Through the south-southeastward street, one could go to Guilai Village, which was connected with Wandan and Donggang, or one could also turn at Linluo to Neipu. However, A-Kau Street was surrounded on three sides by water currents: by the Lower Tamsui River on the west, by the Fanzailiao River and the Wuluo River on the north, and by the Ailiao River and Donggang River and their tributaries on the southeast. Lack of bridges and discontinuity of the roads conditioned the traffic of humans and vehicles (see Fig. 2).

As the Office of the Governor-General decided to establish A-Kau Prefecture, the construction of the Office of A-Kau Prefecture and the operation of Taiwan Sugar Corporation further consolidated the status of A-Kau Street. A 1909 map where A-Kau Prefecture was illustrated (see Fig. 4) showed that the Office of A-Kau Prefecture sat to the north of A-Kau Street, and around the Office were Pingtung Temple House, Martial Arts Hall, and Pingtung Park. Though the sugar factory was not in the map, the rail tracks across the south of A-Kau Street demonstrated that A-Kau (Sugar) Factory, A-Kau Street and Jiuqutang Station were already connected in transportation. Authorities also had plans for A-Kau Street and its neighboring land. In the street areas where the density of population was higher, some blocks and alleys were mapped out, one of which was reserved for public and elementary schools. The post office and the police station were allocated on the main path leading from A-Kau Street to the sugar factory. Their locations were carefully selected by the government, as they represented the convenience of communication and finance and the mechanism of watch and 
control respectively. The serum workshop further outside was meant to prevent the infection and dissemination of rinderpest (or cattle plague) [8], a measure to ensure the health of cattle, an agriculturally important animal for land plowing and goods carrying.

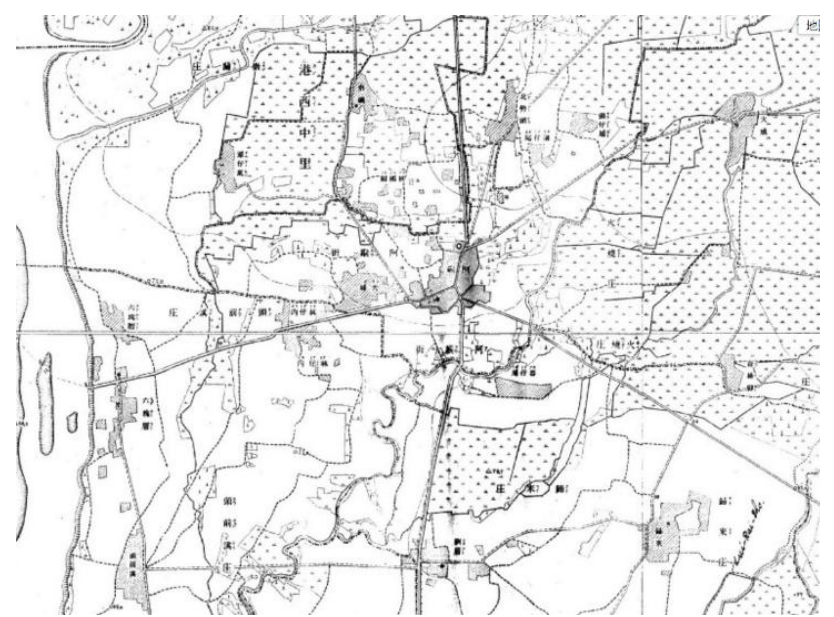

Fig. 3. A-Kau Street on the neighborhood map of Taiwan [17].

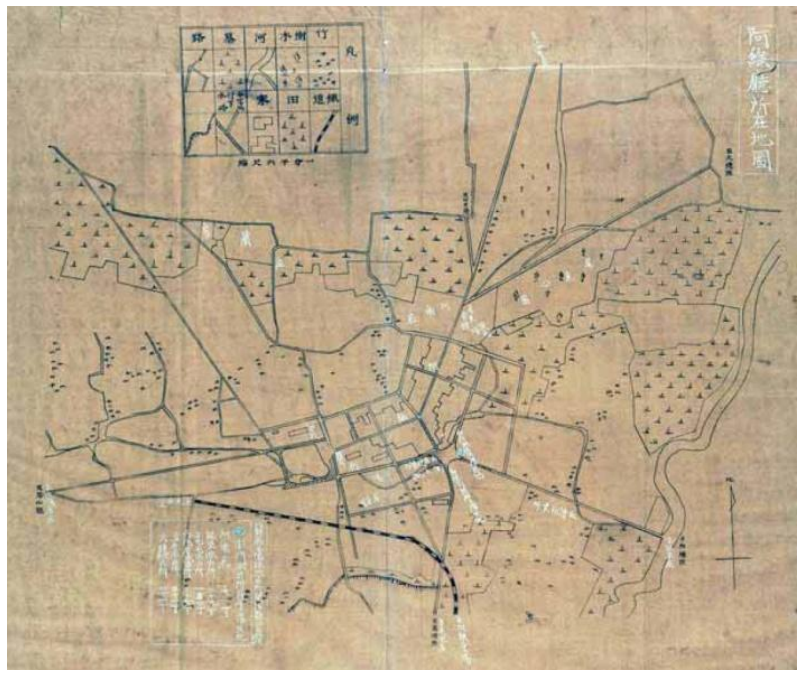

Fig. 4. A-Kau prefecture map in 1909 [18]

\section{B. The Spatial Layout of the Urban Development Plans}

Several years into the initiation of the Office of the Governor-General's urban development policy, many settlements, villages and towns in Taiwan saw obvious improvements, whether in general appearance, spatial broadness, or environmental sanitation. In comparison, A-Kau Street was relatively backward in these aspects, despite its being the administrative center for the strategic industry in southern Taiwan. With the realization of the bridge building project in 1913 which made it possible for the train to cross the Lower Tamsui River, the Pingtung Plain was able to link up with plains in western Taiwan for more potential advancement. The development plan for A-Kau Street, the first urban plan for Pingtung City approved by the Office of the Governor-General, was announced in early 1913 (see Fig. 5). The plan broadened the total area of A-Kau Street from 107,377 ping to 819,218 ping (1 ping is about 3.3058 square meters) [19], realized in two stages and expected to accommodate a population of 42,000 [19]. In fact, as the authorities of A-Kau Prefecture hoped to cash in on the chance of urban planning to construct a new city with appropriate space distribution so as to reflect the importance of the Prefecture Office and the particular industry here, a proposal was submitted to the government. However, the Office of the Governor-General considered the project too big and wanted to locate A-Kau Station at the center of the new city [8], [19], so the scope of the plan was reduced considerably.

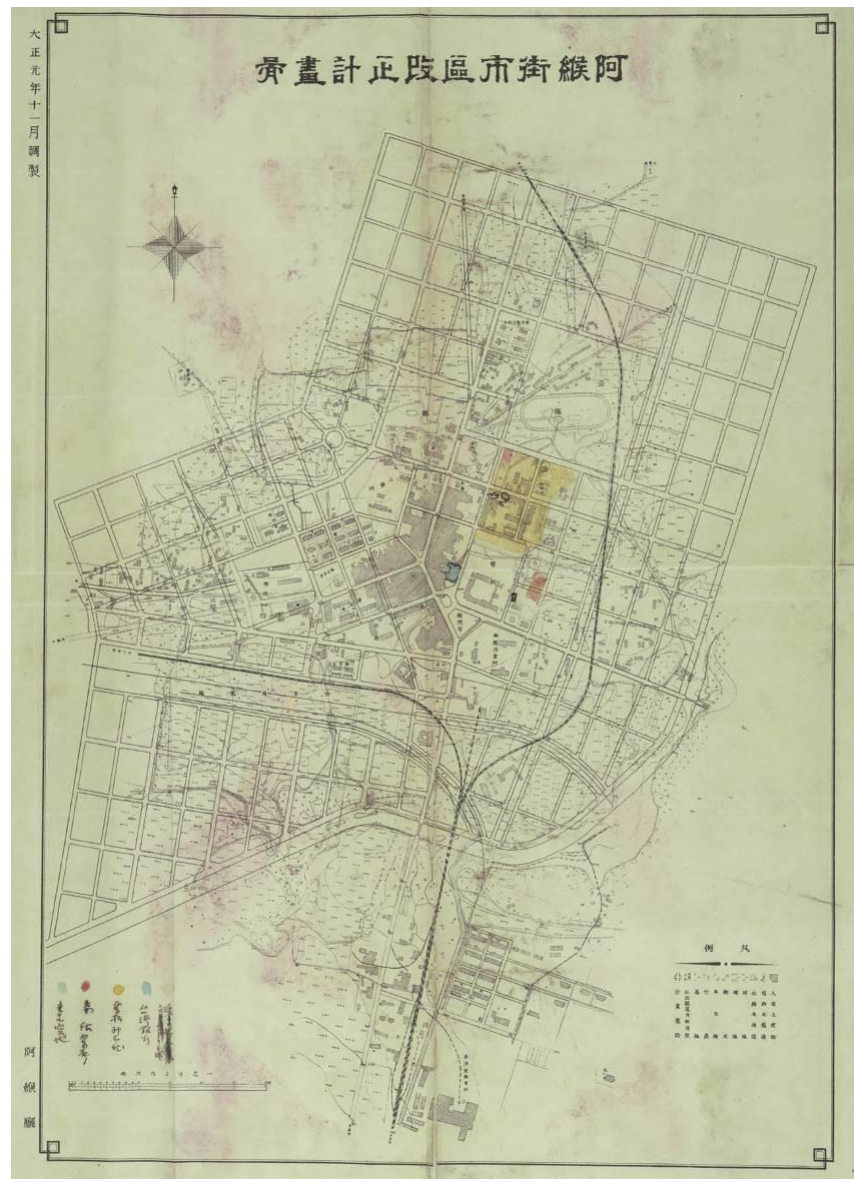

Fig. 5. Development plan map of A-Kau street [19].

(Approved in 1913 by the Office of the Governor-General)

From the map, one can see the downtown area was around the train station parking space north of the regulated Fanzaipu River (now the Wannian River, on the upper stretches of Niuchou River) and the space around A-Kau Street, which did not include the factory of Taiwan Sugar Corporation at the north. Even so, in terms of the general configuration of the city, the train station area, A-Kau Street, and the Taiwan Sugar factory stood at three major spots like a tripod. Not far from each other, they were well-connected and mutually helpful. The exclusion of the sugar factory from the urban plan gave it the benefit of free use, which, together with the wide stretch of land around it, paved the way for future expansion of the factory premises.

In the spatial design of the urban scheme, since the train station was built in connection with the Pingtung railway line and the sugar factory line, the reserved passageways naturally became the main axial space at the station. The surrounding streets and blocks developed from the axis, forming either a parallel or a perpendicular relation with it, and so the contour of the city came into shape. In developing the old A-Kau Street area, the architect adopted the strategy of basing the construction on the existing main streets [8], [19]. The 
north-northeastward street (now the northern section of Fuxing North Road) and the west-southwestward street (now Yongfu Road) formed the coordinate on which surrounding streets and blocks were shaped and lined parallel or perpendicularly into two zones, thus expanding the domain of A-Kau Street. Conditioned by three spatial axes, the city was divided into three zones, each belonging to a separate axial line, each shaping its own configuration.

\section{Establishment of Outside Communication}

As the Office of the Governor-General strategically made A-Kau Street the spatial center of the Pingtung Plain, how to create transportational conditions to facilitate the integration of resources in different zones became the key question. In spite of its being adjacent to the Lower Tamsui River, A-Kau Street could not rely on the water for transportation, because the rapid currents in the river were not fit for vessel navigation and the watercourse was not connectable to all the sugarcane plantations. On the other hand, technology in manufacturing of trains and laying of railroad tracks was already advanced in the 19th century, and the industrialized nations in the West had constructed railway lines across their territories as part of the infrastructure. Keen to promote the Westernization cause, the Japanese authorities naturally gave the first priority to the railway construction.

In order to efficiently collect raw sugarcane from different fields for further processing, Taiwan Sugar Corporation continuously and widely paved rail lines to form a network of transportation, where A-Kau Sugar Factory was the center (see Fig. 6). Likewise, for the purpose of cane sugar shipment the Office of the Governor-General extended the north-south rail trunk line to the Pingtung Plain and made A-Kau Station the transit to link up with the rail line from A-Kau Sugar Factory, distribute goods and material, and carry personnel. In the urban development plan, the parking space was crossed from north to south by an existing sugar railway and two reserved passageways. Obviously, the passageway in the center was to be part of the Pingtung rail line, and was the principle axis in the whole parking space. The cane sugar line which connected A-Kau Sugar Factory and Jiuquang lay between the Pingtung railway and the downtown area. Since it posed as an obstacle to the general development of the city, it was to be relocated to the reserved southern passageway. Moreover, the sugar-conveying line between Aligang and A-Kau Sugar Factory ran through the new area from the east, resulting in disruption of the totality of many streets and blocks. Because of this, the planner came up with a new passageway as the destination of the sugar line's later relocation to reduce the negative impact caused by the traversing rail.

In contrast with the regulated railway development, the highway traffic between A-Kau Street and its surrounding villages presented a broken and discontinuous picture owing to the scattering and sprawling streams (see Fig. 7). The transportation network in the urban planning was designed primarily for downtown traffic, leaving little consideration for the connection with settlements on the periphery. Therefore, the network of roads linking the peripheral villages was yet to be completed.

\section{Design of Streets and Blocks}

The integration of the Pingtung rail section and the cane sugar line gave A-Kau Street the most advantageous position in transportation. However, the spatial development of the emerging city depended on the reasonable division and use of the land, and an optimum array of streets and blocks was a crucial factor, because it would become the local spatial keynote that would not be easily changed, particularly as the space within the streets and blocks would be further divided, with private ownership of the properties on the land gradually established and buildings in the area falling into place one by one.

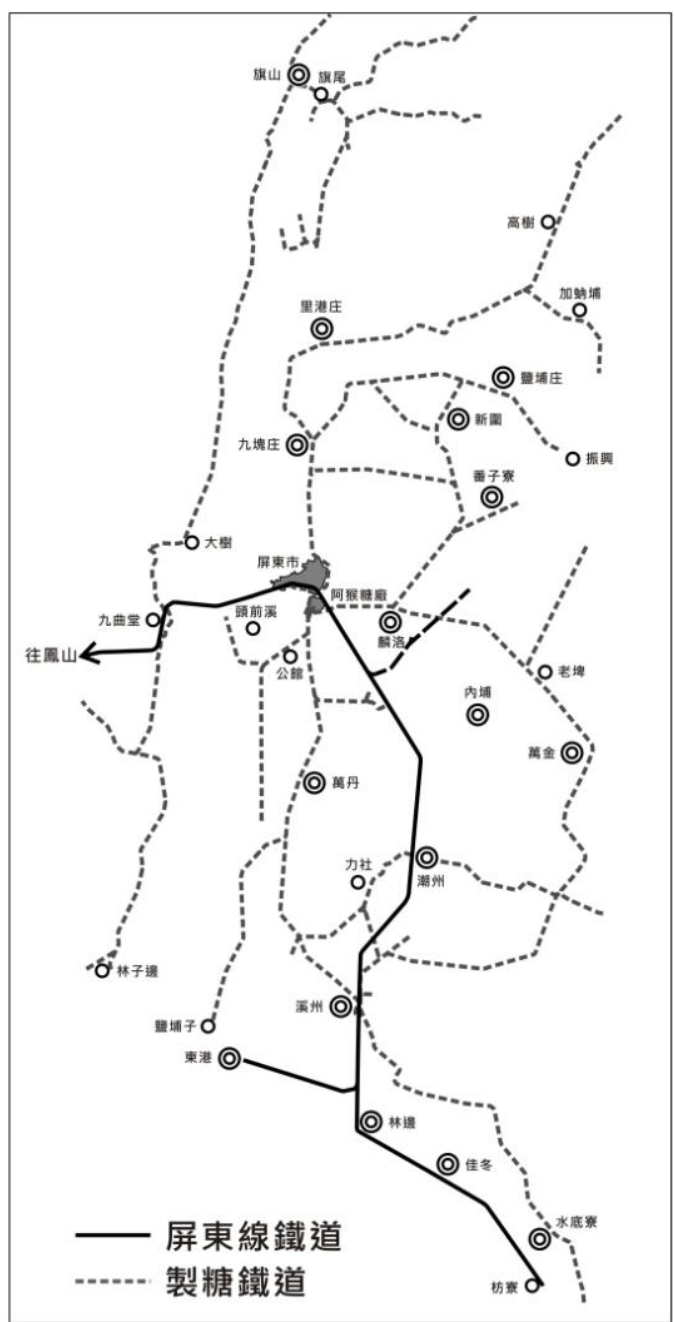

Fig. 6. The railway network on the pingtung plain in the topographic map of Taiwan.

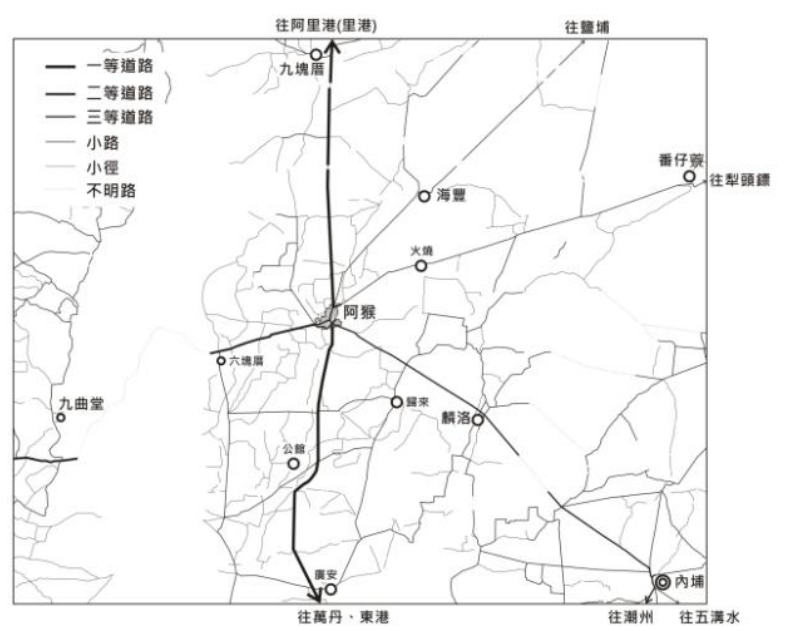

Fig. 7. The network of pathways around A-Kau Street in the neighborhood map of Taiwan. 
As far as the planning of street divisions was concerned, square and rectangular blocks, each 72 by 110 meters in area, were preferred by the architects [8], [19]. The plan divided the three zones into streets and blocks, and in the areas bordering two zones there appeared non-rectangular blocks, including triangular, trapezoidal, and even round ones. Necessary adjustments were made to ensure smooth traffic and unobstructed connection of pathways. Despite the preference for right-angled blocks, flexibility of block shapes was an important factor in accommodating the turn of the Pingtung rail line passageways and the curving of the regulated rivers.

In terms of functional division of land, this development plan was only embryonic. The plan drafted nine types of land use: general land, land for parks, land for public buildings, land for parking, land for highways, land for railroads, land for ponds, land for extended roads, and land for extended lower sections of rivers [8], [19]. Of them, the one occupying the largest area was the general land, totaling 468,864 ping $(57.2 \%)$, which was reserved for development and use by the private sector. The second largest was land for highways, 149,845 ping in area (18.3\%), followed by 38,500 ping (4.7\%) of land for parks and a 26,945-ping land for public buildings (3.3\%). Besides, the land for parking and railway accounted for 21,645 ping (2.6\%) and 12,790 ping (1.6\%) respectively. What remained was land for other public uses. Under the principle of demarcation by usage, the existing premises of A-Kau Prefecture, the parks, the serum workshop, the post office, the markets, and the public schools all had their own blocks for their exclusive purpose. The same also applied to newly established hospitals and independent schools. What is noteworthy here is that these public constructions all surrounded the old A-Kau Street.

A-Kau Street was originally a rural settlement, with a small population and light traffic on the narrow street. Following the new trend, the new development plan gave all the streets in town a new width among the six new standardized sizes: $10 \cdot 8 \cdot 6 \cdot 5 \cdot 4$ and 2.5 jian ( 1 jian is about 1.8181 meters) [8], [19]. There was only one street 10 jian (18.18 meters) in width, which ran in front of A-Kau Station. Spatially speaking, this arrangement served three purposes: to meet the growing need for transit sparked by railway construction, to integrate the traffic around the train station and A-Kau Street, and to emphasize the importance of A-Kau Station in the whole project. Then, there were only two 8 jian (about 14.54 meters) wide streets, one along the Fanzailiao River, the eastern border of the city; the other lay on the south side of the new park. The 10.91-meter-wide (6 jian) streets and 7.27-meter-wide (4 jian) streets were the most commonly seen in town, the former constituting the main avenues, the latter forming local community lanes and alleys. Streets 9.09 meters $(5$ jian) in width were a new specification for old A-Kau Street. As to the 4.55-meter-wide (2.5 jian) streets, they were designed for subdivision within street blocks. On the whole, the design of the street breadths was conservative, but they were more economical.

\section{E. Local Adjustments in the Urban Development Plan}

Seventeen years after the initiation of the urban development plan, a new development plan for Pingtung
Street took the place of the old one (see Fig. 8). Except for confirmation of street name changes, the new one was essentially a partial modification of the old one in terms of space. In this phase, not only did Pingtung Street flourish because of the cane sugar industry, but a brand-new look and climate was brought by the succession of major constructions (the airfield and the Lower Tamsui River work) and establishment of official apparatuses (the air training program for the police and the Eighth Aviation Regiment of the Japanese Army). However, the new plan was rather conservative in that it did not put forward any vision for further advancement.

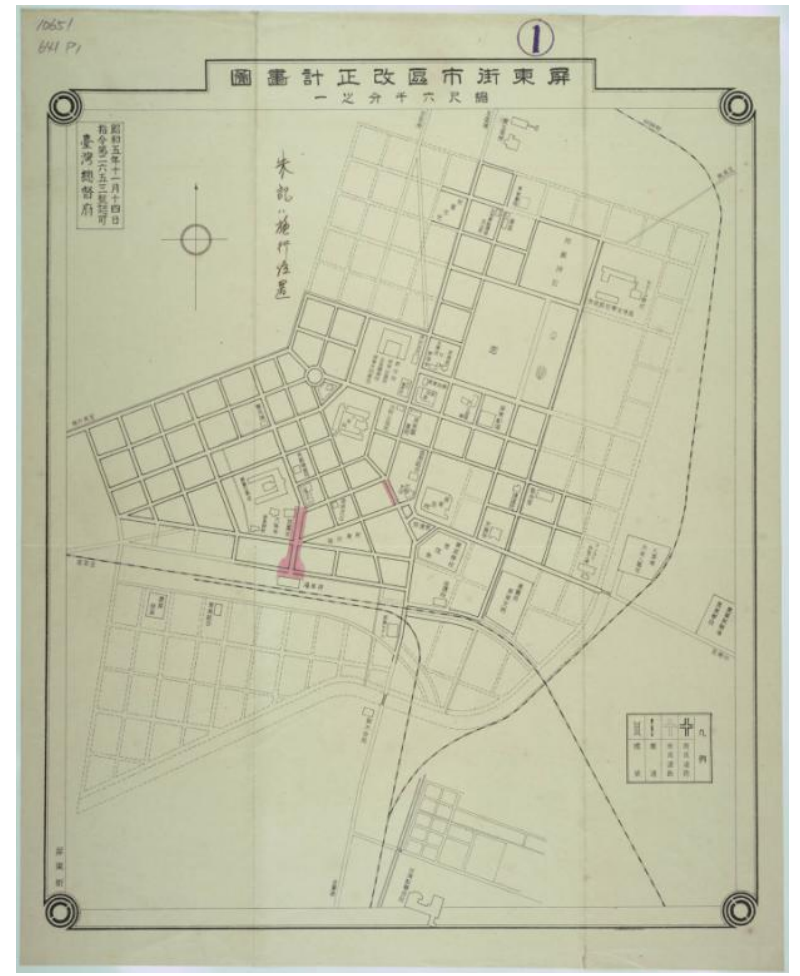

Fig. 8. The development plan map of pingtung street [20].

(Approved by the Office of the Governor-General in 1930)

Basically, the new plan did not broaden the scope of the old one, but it put much effort in developing outside communication. In railway traffic, the Pingtung line dominated the space of the station area, and Pingtung Station fronting the big avenue became the hub of commute for the working staff. The former sugar rail lines were removed to a parallel site on the south of Pingtung railway passageways, but the initially proposed passageways for the sugar rail were not used, probably as an adjustment to the alteration of the Ligang sugar railway line. The new Ligang line for conveying cane sugar did not use the passageways reserved for it but emerged totally outside of the planned area. This served to reduce the negative impact on urban development. The reserved passageways for the Ligang line were incorporated to their neighboring blocks. As for road communication, the new map indicated that Ligang, Yanpu, and Changxing could be reached via highways in the north, and roads that led to Chaozhou in the east and Donggang in the south were also available.

More than ten years of rapid development saw Pingtung Street changed in several obvious aspects. In the first place, with the administrative reform, A-Kau Prefecture Office 
became the Pingtung County Office, and the momentum it brought to the development of the surrounding blocks was gaining. Administrative and judicial offices of the government clustered around the County Office, and cultural and recreational facilities were also installed here. Besides, the thriving economy also attracted financial enterprises, which set up their branch offices preferably in the old A-Kau Street area not far from the sugar factory. Likewise, the booming agricultural activities also caused marketing agents of agricultural products to arise, with their establishments adjacent to the Pingtung railroad line for convenience of transportation. Moreover, with the increasing growth of population, education of the younger generation was keenly felt, and so girls' schools, high schools, and agricultural schools were in place accordingly. Meanwhile, Japanese religious institutions were also installed, scattered in many nooks and crannies of the city. These constructions and installations were basically embedded in their respective blocks according to the blueprint of the plan. However, the spatial need for A-Kau shinto shrines, girls' public schools, and girls' high schools prompted the new plan to adjust and alter some streets and blocks in the undeveloped northeastern area.

As far as the virtual development of the city is concerned, the area bounded by old A-Kau Street, Pingtung Train Station, and the airfield had had its streets completed, with clearly defined blocks where financial, commercial, recreational, medical and educational institutions made their entry successively. This nucleus of the city led the general development. By contrast, with a lot fewer constructions, the regions south of the train station, north of the County Office, and east of the park were slower in development. However, this left more room for future modification and improvement.

\section{The SPATIAL EXPANSION AND INTEGRATION STRATEGy OF THE URBAN REDEVELOPMENT PLAN}

After twenty years of galloping growth, the urban development plan for Pingtung Street gradually failed to meet the needs of local economic expansion. At the same time, a more advanced and comprehensive idea of urban planning spread to Taiwan, incubating a more systematic planning that was to replace the former simplistic development plans [21]. As a result, what with the keen demand for space and the new conception of urban planning, a new redevelopment plan for Pingtung City was born. With the help of the railway and highway systems, Pingtung City further dominated the development of the Pingtung Plain.

\section{A. The Formation of Spatial Cores on the Pingtung Plain}

The completion of the Pingtung railway section successfully broke the barrier to the north-south trunk line and, with the extension of the sugar rail line, achieved the full effect of clustering around railroad tracks, making A-Kau Street the major city on the Pingtung Plain. However, though transportation on the Pingtung railway line was busy, the traffic was linear rather than extending in all directions, benefiting very few zones. Similarly, despite the forming of network in the sugar-carrying lines, connection was only between sugarcane fields and factories. This also brought very little convenience to the general traffic in the settlements and villages. Besides, the vehicles on the tracks were designed for conveying sugarcane crops. For humans to travel on them might entail some risks in safety. Hence, this rail system was incapable of meeting the growing demand for transportation on the Plain. A free, unobstructed network of roads and pathways was better able to handle the situation, but proper terrain was needed for its development.

The flood control project for the Lower Tamsui River was scheduled to be completed in 1933, but the completion was delayed for five years. The original purpose was to tackle the chronic flood problems on the Pingtung Plain, but it also helped to integrate the segmented space on the Plain, for the project greatly reduced the number of streams and shrank the riverbed and marshy area, making the construction of roads and bridges easier and the communication between villages more convenient (see Fig. 9). Subsequently, the basic network of public roads was gradually formed on the Pingtung Plain, and the central status of Pingtung City was further strengthened. Still, it remained necessary to link up with the north-south highway system. With the completion of the jindou bridge (人道橋, literally "pedestrian bridge") about 1.5 kilometers south of the rail bridge over the Lower Tamsui River, the Pingtung Plain finally gained easy access to the plains in western Taiwan, linking the north-south highway with local roads. Already enjoying an advantageous position with the rail traffic, Pingtung City now took a step forward to become the spatial nucleus of the Pingtung Plain.

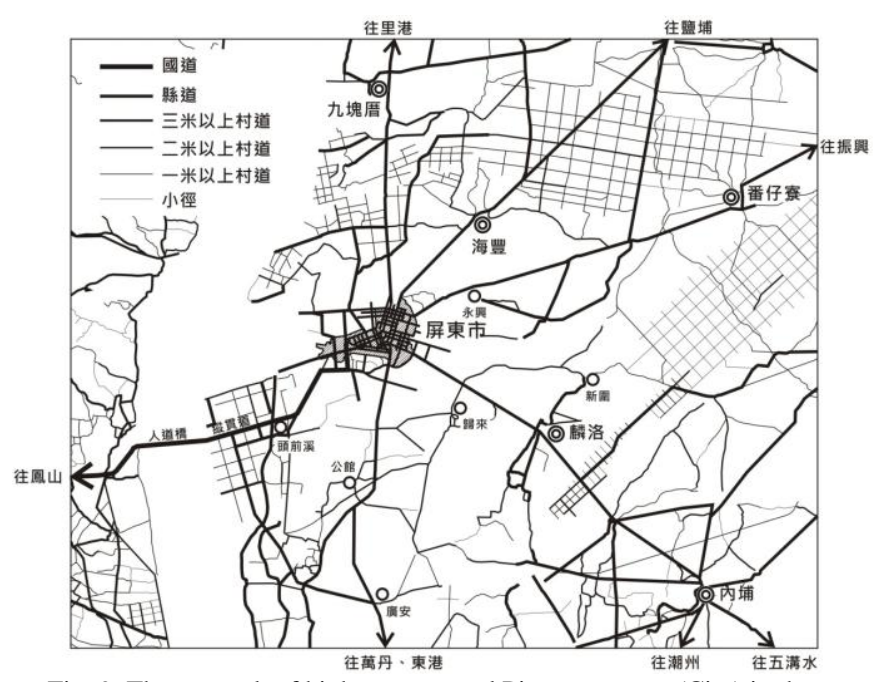

Fig. 9. The network of highways around Pingtung street (City) in the topographic map of Taiwan.

\section{B. The Great Expansion of the Downtown Space}

The upgrade of Pingtung Street to a prefecture-administered city testified to the Office of the Governor-General's great expectations of Pingtung City. Therefore, just one year after the approval of the upgrade in 1933, another map of Urban Redevelopment Plan for Pingtung City, authored by Kobama Joukou, was approved by the Office of the Governor-General, but it was not announced until three years later [22]. The original copy of the map was lost, but in what is now Pingtung County Hall there was a partial version, pieced incompletely together from the original map (see Fig. 10). Since the pieces were not fitted well together and the paper was yellowed and torn, the map was not easy to read. However, in a collective map of 
1939 archived by the Pingtung City Office registering the street development of the previous year (see Fig. 11), the spatial arrangement of the urban plan approved in 1934 could be clearly discerned. However, on the upper right of the map was inscribed "The Urban Planning Plot for Pingtung," different from the title of the original copy. In terms of scope, this urban planning scheme was far broader than the previous development plans (see Fig. 12), probably a technical rebound from the twenty-year confinement to the old limited space on which developments progressed at breakneck speed.

As far as spatial strategy is concerned, the new redevelopment plan was founded on the old one and expanded outward from the front of the train station. The land for sugar factories in the southeast was excluded from the city center so that the area had some flexibility in developing in its own way. The Ligang line for sugar production seemed no longer included in the redevelopment plan. In the new downtown area, the zone between old A-Kau Street, the train station, and the airfield was constructed the most, for it possessed the advantage of being adjacent to the rail station and the Eighth Aviation Regiment of the Japanese Army. Besides, the area around the back of the train station also saw greater alteration and expansion, such as the thorough transformation of the street block system and the appearance of many extensive blocks whose purposes were not clear. This might be a preliminary arrangement for the joining of the road to Fengshan of Kaohsiung and the future development of industries. The area in the north and east showed a more balanced contour of urban development, a spatial effect from the integration of the beltline.

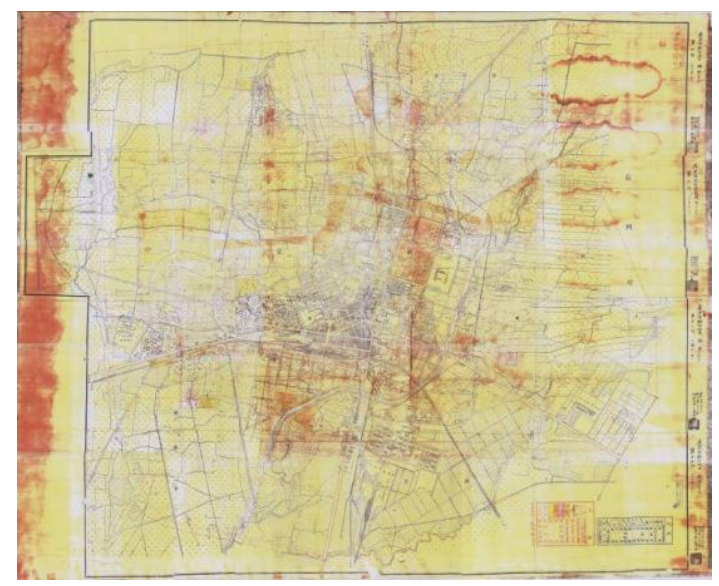

Fig. 10. The redevelopment plan map of Pingtung city [23]. (Approved by the Office of the Governor-General in 1934. The notes on the right margin show that the map was approved by the Office of the Governor-General on March 7, 1934 (approval number 1383). The "Confidential" stamp on the upper right corner reveals that the government regarded it as a classified document.).

Despite the drastic expansion of the downtown area as a result of the redevelopment plan, the use of land did not see any new purpose. Except the land for parks and schools, the streets and blocks did not mark any specific use. The number of parks increased from one to twenty-eight, though with varying sizes. Their distribution fell into two types: one featured an east-west green-belt passageway, bordered by eleven parks from Park 2 in the east to Park 8 in the west; the other was characterized by evenly distributed parks in the zones to improve the living environment. Besides, an even distribution of schools was implemented, whose number increased from five to eleven, to give students from different zones a nearby school to attend.

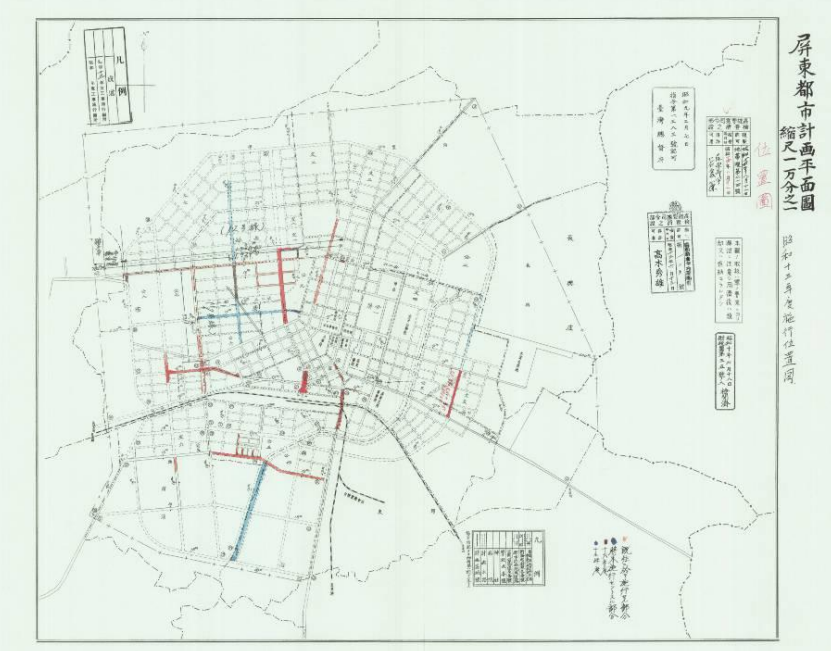

Fig. 11. The urban planning plot for Pingtung [24].

(Approved in 1934. Since this map was a classified document of the military, it required the approval of the Fortress Headquarters of Kaohsiung.)

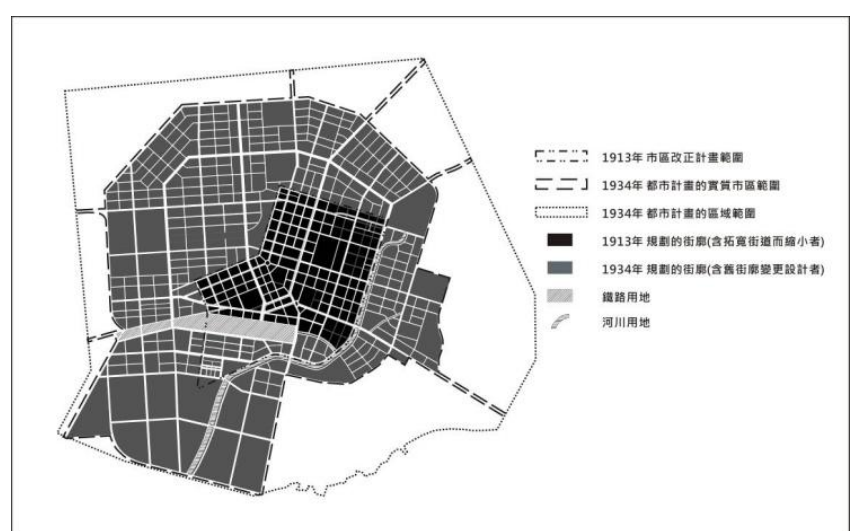

Fig. 12. The spatial expansion in the urban planning for Pingtung city in the Japanese occupation period.

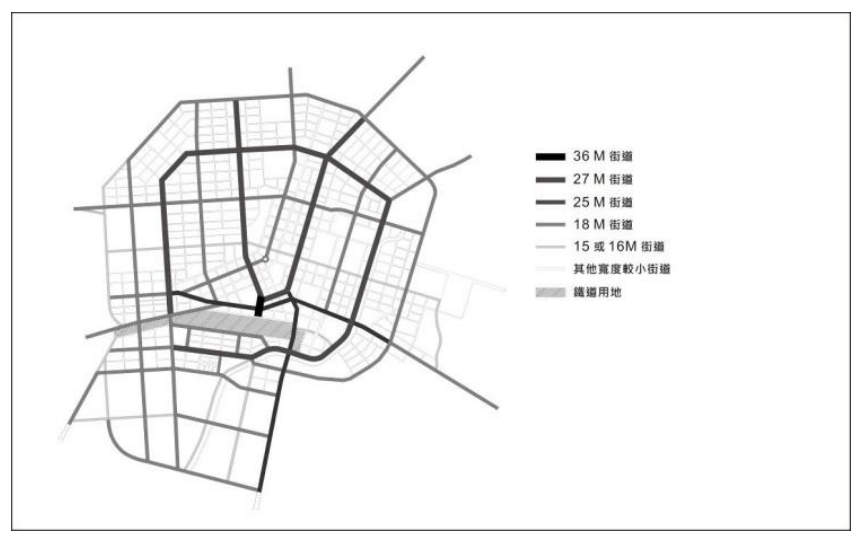

Fig. 13. The street system in the urban planning plot for Pingtung.

\section{Systematic Integration of Streets}

From the new redevelopment plan can be seen new street networks that were used to integrate connector roads with city streets. There are three aspects to this network scheme: linking roads that extended to the peripheral settlements and villages, creating two encircling roads for the city, and reshaping the space of the city nucleus to improve traffic (see Fig. 13). As a result, the new Pingtung City had a brand-new appearance of street arrays.

With the gradual formation of road network on the 
Pingtung Plain, the central Pingtung City played a more significant role. The plan plot exhibited a clear-cut scheme of connector roads: the linkage of the villages on the periphery with the city through highways of eighteen (or twenty-five) meters wide. This was actually a reasonable strategy considering the advent of the age of highways. Most of the connector highways were existing roads which underwent widening. Representative was the newly constructed southwest trunk road (now Jianguo Road) that led to the jindou bridge of the Lower Tamsui River and integrated the traffic system between the Pingtung region and Taiwan's western plains.

Containing an inner circle and an outer one, the roads encircling the city were meant to relieve the dense network of streets in the city center. However, owing to the space-splitting by the railroads and the blockage of the cane sugar factories, the encircling roads were not undeterred in its circular routes, particularly in the zone south of the railway. In terms of breadth, the inner circle was wider than the outer one, with a basic width of twenty-seven meters (excepting a little section) compared with the eighteen meters' width of the outer circle. This was obviously in consideration of the coming of the age of automobiles.

In the old development plans, the main streets in the city were mostly 9.09 or 10.91 meters wide, clearly insufficient for a changed Pingtung City. The widening of the existing streets was a way to reshape the space of the city center and ameliorate the quality of transportation. Examples included the transforming of the 18.18-meter street in front of the train station into a 36-meter avenue, the widening of the extending streets on the left and on the right of the train-station avenue from 10.91 and 9.09 meters respectively to twenty-seven meters uniformly, and the expanding of the east-west street crossly connected with the train-station avenue from 10.91 meters to 36 meters in breadth. The integration of these widened roads made the city center more gradationally structured and spacious, giving the city a new facade.

\section{Equal and Balanced Development of Railroads and Highways}

For a long time, the Lower Tamsui River had posed as an obstacle to communications with the outside, and the floods it caused through its sprawling streams had been a major reason for the retarded growth of the Pingtung Plain. With the completion of the Pingtung rail line and the extension of the sugar rail network, A-Kau Street soon became the hub that connected the Pingtung area with western Taiwan and the platform where labor, material and resources could be synergized. The urban redevelopment plan was a catalyst for the importance of A-Kau Street through the spatial reform it introduced. The railroad was A-Kau Street's core interests.

The step-by-step achievement of the flood control projects for the Lower Tamsui River contributed to the gradual spatial integration of the Pingtung Plain and the increased feasibility of highway network construction. After all, the interlaced roads and streets were more accessible to each family and better able to attract labor and resources, though automobiles were still rare at the time. In this light, the broader road arrangement in Pingtung City's urban planning was a very daunting attempt in that it would take quite a long time for practical demand for it to occur. Such an arrangement should have been inspired by the Western concept of urban planning. Notwithstanding, the development of highways did not nullify the importance of railroads, for the volume of railway transportation was unparalleled by that of highway, especially in terms of cane sugar carriage. Therefore, on the one hand the advantageous position of Pingtung City was enhanced through the integrated arrangement and transformation of downtown streets and outer circular highways; on the other hand, the shaping of the city center served to strengthen the status of the train station as the hub for transit. As a result, the new prefecture-controlled city benefited from both aspects.

\section{E. Extension of the Airport as an Obstacle to Urban Development}

A military site, Pingtung Airport was never included in the urban scheme. However, the ever-expanding airport gradually formed an obstacle to the growth of Pingtung City. The airfield was poorly designed in terms of spatial arrangement. It was situated on the west side of A-Kau Street on the plain of the Lower Tamsui River, but its runway was directed eastward facing A-Kau Street. In a time when techniques of airplane manufacture were still rather basic, such a design of the airport did not cause much inconvenience. After all, the old-style aircraft did not require too long a runway, the angle for takeoff was relatively sharp, and airplanes were relatively light and slow back then. Besides, the number of airplanes for the constabulary aviation training program was limited. That was why A-Kau Street remained unaffected by the ground for aircraft for some time. However, things began to change when the Eighth Aviation Regiment of the Japanese Army took over the field.

This airport was not only the base for the first aviation regiment stationed in Taiwan, but also the bridgehead for the extension of Japanese power to Southeast Asia and South China. The handover of the aviation field to the Regiment resulted in the continued increase of airplanes and the improvement of their scale, function and speed, which meant the needs to install more facilities, lengthen the runway, and lower the angle of the plane's takeoff. Consequently, the space of Pingtung City was constrained by the air ground, though the urban planning plot revealed nothing about the airport extension. Consideration of military secrets kept the airfield from view on the map of the redevelopment plan for Pingtung City; the planning plot was even classified as confidential by the military. As the Second World War grew increasingly intense, the original airfield became inadequate (see Fig. 14). Thus, the Japanese military added a new airfield about two kilometers north of the original airport (South Airport), and built an approach road along the river to connect the two aviation grounds.

To the Pingtung City in the Japanese occupation period, the two airports did not cause any impact to the urban redevelopment plan, which still had a lot of downtown land for development. Moreover, at the time there was no need or techniques to construct tall buildings, so flight safety was not a problem. However, as far as long-term development is concerned, the aviation grounds completely ruled out the possibility of Pingtung City's extension to the northwestern suburbs, resulting in the inconvenience where connection with peripheral villages in the north and west had to be done 
through roundabout routes. Also, the degree of development and the height of buildings in the central area of the city were stunted, foreshadowing the limited development of Pingtung City after World War Two.

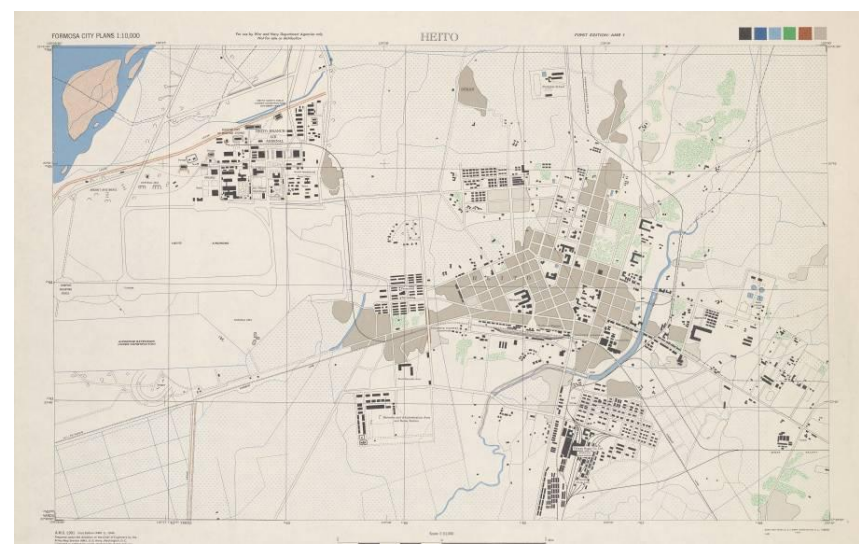

Fig. 14. The Pingtung city and South Airport in the map of the American Army during World War II (1944) [25].

\section{CONCLUSION}

Like other cities in Taiwan, the development of the present Pingtung City owed much to the urban planning of the Japanese rulers in the colonial period. From what was described above, one can see two stages of planning, varying with each other significantly in spatial strategy and design. The urban development plan was specific in developing A-Kau Street through construction of railroads, for only by doing so could labor, material, and resources be efficiently gathered and integrated to promote the cane sugar industry. That was why the parking space of A-Kau Street became the hub where the north-south rail trunk line and the sugar-carrying railway met on the Pingtung Plain, and A-Kau Station became the main gate through which activities of every sort came in and out. In terms of the downtown arrangement, however, the strategy of dividing the city center into three zones with three streets as spatial axes was crude and lacking in comprehensive consideration. This suggests that the planner might have proposed the scheme in a rush to promote local construction or have not been able to handle a plan as large-scale as this should have been.

After twenty years of urban development, the accumulated experience enabled authorities to come up with a clearer, more comprehensive picture of city planning, though constrained by the sugar factories and airports. Pingtung Station had long been the transit center for labor and resources. Knowing the situation, Kobama Joukou sought to integrate the outer highway system through building connector roads and enhance the circulation of labor and resources. The inner and outer circular highways marked the central status of this upgraded city administered by the prefecture. The image of the city center was reshaped through broadening the streets and raising the quality of road traffic. The widened streets demonstrated that a new age of automobiles was coming and that cars were becoming popular vehicles in industrialized countries. The convenience and mobility of automobiles forced urban planners to make it part of their schemes, and cities in Taiwan had to follow this trend and make plans accordingly.
Pingtung City depended a lot on the cane sugar industry, and its development was closely associated with the rise and fall of the industry. Although sugar production has declined, the prime location of the former factories can be utilized in different ways, and the old railway for sugar transportation can also be developed into a tourist spot. In the global current of industrialization, the Japanese brought new ways of developing industries to Taiwan, to A-Kau, and introduced the Western methods of planning and building the infrastructure to the Pingtung Plain. Compared with other prefecture-administered cities, Pingtung City was rare in that it was planned and developed specifically for a particular industry. It was precisely for this reason that public transport facilities played a key role in the urban planning. The shift of emphasis from railroads to highways indicated that the Office of the Governor-General was actively borrowing the Western sciences and techniques in transportation to help the renovated streets and roads to accommodate automobiles and increase traffic efficiency.

\section{REFERENCES}

[1] Anonymous, Map of Taiwan, Taipei: National Central Library, 1982.

[2] Y. Xiao, Travel Notes of the Japanese Army in A-Kau in 1895, Pingtung Literature, 2003, pp. 70-86.

[3] Corporate sugar industry association, Contemporary History of the Japanese Sugar Industry, vol. 1, Kaohsiung: Corporate Taiwan Sugar Cultural Society, 2007.

[4] Y. Cao, "Taiwan under Dutch and Spanish rule," in Study of Early Taiwan History, Yonghe Cao, ed. Taipei: Linking Publishing, 1984, pp. 25-44.

[5] H. Fang, "Suburbs of Tainan," Fang Hao's Selection of Drafts 60 to 64, Taipei: Taiwan Student Book, 1974, pp. 273-295.

[6] W. Shi, "Indigenous products and snacks of trade unions in Tainan," Taiwan Literature, vol. 31, no. 4, 1980, pp. 70-96.

[7] T. Yanaihara, Taiwan under Japanese Imperialist Rule, Taipei: Pamier Bookstore, 1987

[8] X. Cai, Urban and Architectural Development of Pingtung City in Taiwan under Japanese Rule, Master's thesis, Department of Architecture, Chung Yuan Christian University, Taoyuan, 2000.

[9] T. Zhuang, The First New Sugar Factory in Pingtung, Nanchang Sugar Corporation, Pingtung Literature, 2001, pp. 61-68.

[10] Y. Yang, Hundred Years of the Sugar Industry in Taiwan, Taipei: Owl Publishing House, 2001.

[11] J. Jian, The Development of the Pingtung Plain and the Relationship between Different Ethnic Groups, Pingtung: Cultural Affairs Department of Pingtung County, 1997.

[12] Z. Hong, "Pingtung's toponyms", Pingtung Literature, 2000, pp. 31-34.

[13] Police station of the Taiwan sotokufu, History of the Taiwan Sotokufu Police (I), Nantou: Taiwan Historica, 2007.

[14] Cultural Affairs Department of Pingtung County, Flood Control Map of the Lower Tamsui River (1927), Pingtung: Pingtung County Government, 2008.

[15] Y. Gu and X. Liao. The use and application of the maps from the Japanese colonial period collected by water resources agency. (2012) qtd. [Online]. Available: http://gis.rchss.sinica.edu.tw/mapdap/wp-content/uploads/2012/04/Th e-Review-and-Application-of-the-Japanese-colonial-period-map-from -the-collection-of-Water-Resources-Agency.pdf

[16] W. Yang, "Water resources of the Gaoping river and the Pingtung Plain," in Collected Essays on Hydrology in Taiwan, Yang Wanquan, ed. Taipei: Department of Geography, National Taiwan Normal University, 2000, pp. 555-579.

[17] Research center for humanities and social sciences, academia Sinica. [Online]. Available: http://gissrv4.sinica.edu.tw/gis/twhgis.aspx

[18] Archives of the Taiwan Sotokufu, Installation of Police Stations for Officers (No. 5159-11), Nantou: Taiwan Historica, 1909.

[19] Archives of the Taiwan Sotokufu, The Urban Planning Plot for A-Kau Street: Decisions Made to Follow the Plot and Proclamations Notified Later (No. 2120-14), Nantou: Taiwan Historica, 1913.

[20] Archives of the Taiwan Sotokufu, Construction Fee of the Urban Development Plan for Pingtung City (No. 10654-3), Nantou: Taiwan Historica, 1936. 
[21] S. Huang, Study of Urban Planning Paradigms in Taiwan under Japanese Rule, Taipei: Urban Planning Lab, Graduate Institute of Civil Engineering, National Taiwan University, 1987.

[22] File of the Taiwan Sotokufu, Communique 3004--Proclamation 112, (2010). [Online]. Available: http://db2.lib.nccu.edu.tw/view/viewImg.php?imgkey=0\&otherImg=0 $071033004 \mathrm{a} 032$

[23] J. Kobama, Urban Redevelopment Plan for Pingtung City, Pingtung: Pingtung County Government, 1934

[24] W. Huang, Urban Development Maps of Taiwan under Japanese Rule, Taipei: SMC Publishing, 2006.

[25] (2014). Center for geographic information science, research center for humanities and social sciences, Academia Sinica. [Online]. Available: $<$ http://www.lib.utexas.edu/maps/ams/formosa_city_plans/txu-oclc-6 572578.jpg

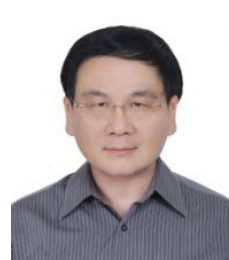

Chuan-Hsiang Hung received his B.S. degree in architecture from National Cheng Kung University, Taiwan, in 1981, and was conferred a diplom-ingenieur (master's) degree and a doktor-ingenieur (Ph.D.) degree from the Faculty of Architecture of RWTH Aachen, Germany, in 1991 and 1999 respectively. He has taught at National Cheng Kung University since 1992 and is currently an associate professor at the Department of Architecture.

His major research interests are planning theory, urban history, urban design and community planning. In recent years, he has focused on the impact of western spatial planning technology on Taiwan's cities, especially the following two subjects: the planning origin of Taiwan's historic ports developed by the Dutch in the 17th century; and the spatial strategy of urban transformation initiated by the policy of westernization in Taiwan under Japanese colonial rule before the end of World War II.

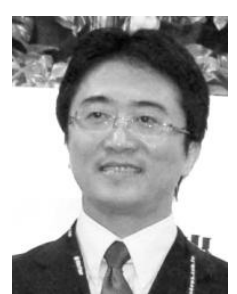

Ming-Hsien Ko was born in Changhua, Taiwan, in July 1966 . He is a Ph.D. student of architecture at National Cheng Kung University in Taiwan. He received his B.S. degree in landscape architecture from Tunghai University in Taiwan in 1989, and obtained his M.L.A. and M. C.R.P. degrees from the Ohio State University, U.S.A., in 1997 and 1999 respectively. From 2002 to 2009 he taught at the Department of Leisure, Leader University (renamed the University of Kang Ning in 2011) in Taiwan where he was a lecturer.

His major research interests are urban form and urban design. He joined the Tainan City Government in 2011 and has since worked as an assistant director general in the Bureau of Urban Development.

Sen-I Tsai was born in Pingtung, Taiwan, in 1957. He received his bachelor degree in architecture from Tamkang University, Taiwan, in 1986, and obtained his M.A. degree from National Cheng Kung University, Taiwan, in 2008. His current research interests include urban design and regional planning. 